Widya Cipta: Jurnal Sekretari dan Manajemen

Volume 4 No. 1 Maret 2020

P-ISSN 2550-0805 E-ISSN 2550-0791

https://doi.org/10.31294/widyacipta.v4i1

\title{
Strategi Taktik Value Dan Kode Promosi Terhadap Motivasi Pembelian Makanan Secara Online Melalui Grab
}

\author{
Ana Ramadhayanti \\ Universitas Bina Sarana Informatika \\ Email : ana.rdx@bsi.ac.id

\begin{tabular}{ccc}
\hline Diterima & Direvisi & Disetujui \\
$26-12-2019$ & $15-01-2020$ & $29-01-2020$ \\
\hline
\end{tabular}

\begin{abstract}
Abstrak - Selain mempermudah pemesanan transportasi dengan menggunakan grab, kini proses pemesanan makanan dengan menggunakan aplikasi grab telah banyak dilakukan, terutama dengan hadirnya diskon promosi yang sering diberikan oleh grab. Selama ini kebanyakan khususnya pengguna grabfood tentunya telah memahami berbagai promosi yang diberikan oleh grab. Jenis promosi yang terdapat dalam grabfood ada yang dalam bentuk potongan harga, pembelian khusus dengan pembayaran menggunakan OVO, penggunaan kode promosi dan bentu lainnya. Pada dasarnya promosi merupakan bagian dari strategi dengan tujuan untuk menarik minat pembeli. Pada penelitian ini kajian yang diteliti adalah promosi yang menggunakan kode promosi. Bentuk kode promosi digunakan pada dasarnya untuk memberikan potongan harga dari harga penjulalan. Namun mesti begitu tidak semua jenis makanan dapat menggunakan kode promosi, hanya makanan bertanda khusus yang menggunkan kode promosi. Untuk memastikan strategi taktik value dan kode promosi terhadap motivasi pembelian makanan secara online melalui grab. Penelitian ini menggunkan metode penelitian kuntittaif dengan menyebarkan kuesioner kepada pengguna grabfood. Hasil uji t parsial atau uji parsial permasing-masing variabel menujukkan bahwa dengan menggunakan SPSS menujukkan hasil bahwa terdapat pengaruh yang signifikan dan positif antara strategi taktik value terhadap motivasi pembelian. Sementara itu untuk kode promosi berpengaruh secara signifikan dan positif terhadap motivasi pembelian. Hasil uji F secara simultan menujukkan terdapat pengaruh antara strategi taktik value dan kode promosi terhadap motivasi pembelian makanan secara online melalui grab. Dengan dilakukannya penelitian ini diharapkan dapat membantu konsumen dalam berbelanja menggunakan kode promosi dari grab.
\end{abstract}

Kata Kunci: Kode Promosi, Motivasi Pembelian, Value.

Abstract - In addition to facilitating ordering transportation by using grab, now the process of ordering food using the grab application has been done a lot, especially with the presence of promotional discounts that are often given by grabs. During this time, most especially grabfood users certainly have understood various promotions given by grab. The types of promotions contained in grabfood are in the form of discounts, special purchases with payment using OVO, the use of promotional codes and other forms. Basically, promotion is part of a strategy with the aim of attracting buyers. In this study, the study studied was a promotion using a promotional code. The promotional code form is used basically to provide discounts from selling prices. But it must be like that not all types of food can use promotional codes, only specially marked foods that use promotional codes. To ensure value tactics strategies and promotional codes for online food purchase motivation through grabs. This study uses a quantitative research method by distributing questionnaires to grabfood users. The results of the partial t test or partial test of each variable show that using SPSS shows that there is a significant and positive influence between the value tactics strategy on purchasing motivation. Meanwhile for the promotional code significantly and positively influences the purchase motivation. The results of the F test simultaneously show that there is an influence between the value tactics strategy and the promotional code on online food purchase motivation through grabs. By doing this research it is hoped that it can help consumers shop using the promotional code from grab.

Keywords: Promotion Code, Purchase Motivation, Value.

http://ejournal.bsi.ac.id/ejurnal/index.php/widyacipta 


\section{PENDAHULUAN}

Sistem pembayaran non tunai saat ini telah banyak dilakukan, mulai dari pembayaran secara non tunai dipusat pembelanjaan seperti mal yang hanya menjual produk makanan dengan sistem pembayaran non tunai. Dapat dibilang sebagai suatu taktik dalam perdagangan, saat ini sistem pembayaran dengan sistem online tidak hanya berbelanja ditoko online namun juga untuk pemesanan makanan melalui aplikasi grab. Dengan pemberian kode promi, setiap transaksi pembelian secara non tunai akan diberikan potongan harga. Sistem pemesanan makanan dengan menggunakan layanan aplikasi online saat ini telah banyak dilakukan oleh masyarakat mulai. Selain lebih cepat dan praktik sistem belanja online sangat diminati masyarakat karena banyak promo yang diberikan terkait pembelian makanan dengan sistem online. Berbagai kode promo diberikan untuk kepada pengguna aplikasi grab, sebagai cara menarik minat pembeli. Dengan menggunakn kode promo makan pembeli akan menikmati potongan dari harga yang terdaftar dalam makanan tersebut. Sebagai Strategi Taktik Value dan Kode Promosi biasanya pemberian kode melalui aplikasi tersebut hanya bisa dilakukan jika pembayaran menggunakan transaksi secara online. Cara pembayaran transaksi online yang dimaksud adalah dengan cara mengisi saldo ovo yang dapat berfungsi sebagai pembayaran. Untuk penggunaan kode promo ini ada syarat dan ketentuan yang berlaku. Dengan adanya sistem diskon promo ditambah dengan penggunaan grab food yang dirasa lebih praktis, cepat serta ditambah lagi dengan pemberian kode promosi maka peluang motivasi pembeli untuk membeli atau memesanan makanan cukup besar. Dengan bersaingnya promo online antara grab dengan pesainganya menimbulkan pembelian makanan dengan menggunakan grab semakin meningkat. Promosi yang sangat besar dari grab yang berupa Kode Promosi pada dasarnya merupakan Strategi Taktik Value untuk mendukung Motivasi Pembelian. Namun pada dasarnya untuk mendukung hal tersebut harus dilakukan penelitian lebih lanjut, maka dalam hal ini peneliti melakukan penelitian Strategi Taktik Value dan Kode Promosi Terhadap Motivasi Pembelian Makanan Secara Online Melalui Grab.

Grab merupakan pesaing terbesar Go-Jek. Berbeda dengan Go-Jek, agen Grab lebih tersebar ke banyak daerah yang ada di Indonesia. Grab juga telah mengakusisi Uber di kawasan Asia Tenggara untuk pelaynana yang lebih baik. Dari segi e-wallet, Grab memiliki OVO yang meruapkan bagian dari open ecosystem (Adiningsih, 2019)
Pemasaran jasa yang diringkas dengan symbol STV yaitu: strategi untuk memenangkan mind share. Taktik untuk memenangkan market share dan value untuk memenangkan heart share (Kurtajaya dalam Manab 2016).

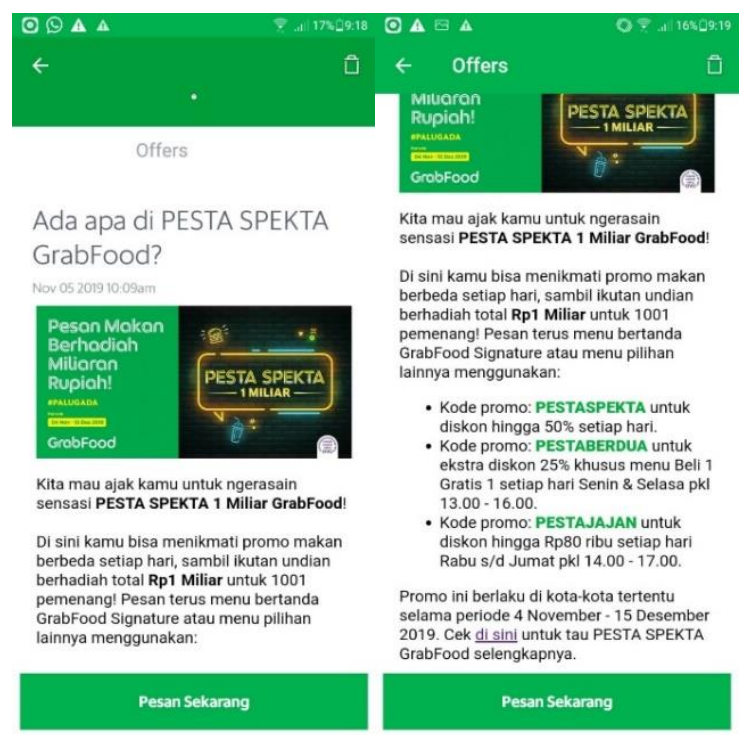

Sumber : (www.grab.com, 2019)

Gambar 1. Kode Promo GrabFood

Jadi strategi berusaha untuk menanamkan nama lembaga beserta produknya dibenak konsumen, ini bertujuan untuk mencapai how to win the market. Sedangkan taktik yang merupakan taktik pemasaran seperti menggunakan berbagai teknik promosi, pengabdian pada masyarakat adalah dalam rangka mengusahakan penguasaan pasar, dengan istilah lain how to penetrate a market. Selanjutnya penawaran value bertujuan untuk merebut tempat dihati konsumen atau how to create an emotions touch. Value pada akhir-akhir ini menjadi dambaan para produsen, karena telah terjadai pergeseran selera konsumen di mana fitur dan benefit tidak cukup lagi untuk memuaskan pelanggan. Pelanggan tidak lagi sebagai makhluk yang rasional tetapi juga emosional, yang membuat peran customer service menjadi sangat penting. Sekarang sangat penting kualitas layanan atau SERQUAL (Service Quality) sebagai alata persaingan yang ampuh untuk mempertahankan langganan membanguan standar kualitas yang excellence. 


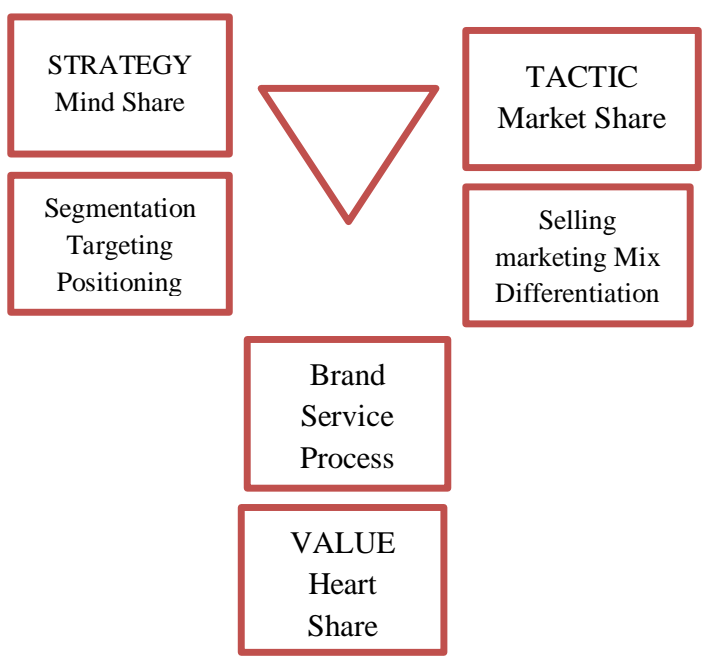

Sumber : (Kurtajaya, dalam Manab 2016) Gambar 2. STV, Modifikasi

Komponen dalam Strategy sebuah perusahaan pertama-tama harus ada pemetaan konsumen, dari mana raja kelompok konsumennya, aspek psikografis dan sebagainya, Setelah diadakan segmentation, maka dapat diarahkan targeting. Apakah semua segmen akan menjadi target market lembaga. Alternative targeting ini tentu bergantung pada ketersediaaan kapasitas persuhaan, masalah keunggulan kompetitif yang dimiliki, situasi persaingan pada umumnya serta kondisi lingkungan, ekonomi, politik dan sebagainya.

TACTIC, ini menyangkut teknik yang digunakan untuk merekrut calon konsumen, apakah akan menggunakan bauran pemasaran, dan elemen bauran yang mana yang diutamakan. Apakah menggunakan teknik promosi, tanpa mempedulikan produk/proses. Dalam hal ini perusahaan harus mampu memposisikan produknya melekatkannya di hati masyarakat. Positioning merupakan penanaman eksistensi produk dan merek atau nama perusahaan.

Positioning is the act of designing the company's offering and image to occupy a distinctive place in the target market's mind.

Kegiatan positioning ini menjadi ajang uji coba bagi produsen kratif, yang dilakukannya terhadap produk yang sudah ada. Positoning ini dapat dilakukan terhdap produk, jasa, lembaga bahkan juga pada pribadi seseorang. Tapi dikatakan oleh Kotler; Positioning is not what you do to a product. Prositioning is what you do to the mind of the prospect. That is, you position the product in the mind of the prospect. [Kotler 2000:298] Jadi inti dari positioning ini aialah bagaimana produsen menciptakan suatu kesan yang lain, yang lebih baik tentang suatu produk yang sudah ada dan ini berpengaruh terhadap calon konsumen.

VALUE, penanaman nilai-nilai yang makin lama makin bermutu, meningkatkan value added bagi konsumen, layanan memusakan akan membuat nama perusahaan semakin bergengsi dan kebanggaan konsumen. Menurut (Rinaldo dan Hardi, 2016) Masih banyak pengusaha yang tidak benar-benar memahami apa arti promosi. Promosi tidak sellau berarti beruapaya menyampaikan pesan secara satu arah. Pendekatan ini sudah tak lagi efektif, karena setiap hari konsumen sudah menerima sangat banyak pesan promosi. Saat menyalakan handphone, setelah bangun tidur, bisa jadi konsumen sudah mendapat SMS promosi.

Menurut (Manap, 2016) Kita bisa menemukan banyak pandangan telah diungkapkan dalam berbagai literatur tentang pengertian promosi, antara lain:

1. Ben M. Enis (1974: 378), defines promotion as communication that inform potential costomers of the existence of products, and persuade them that those products have want satisfying capabilities.

2. William J. Stanton (1981:445) menyatakan "Basically, promotion is an exercise in information, persuasion and conversely, a person who is persuaded is also being informed".

Menurut (Cannon, 2009) Kesulitan dasar dalam proses komuniaksi terjadi selama pengodean dan penguraian kode. Pengodean (encoding) adalah sumber yang menentukan apa yang ingin dikatakannya dan menerjemahkan ke dalam kata-kata atau simbol-simbol yang akan mempunyai arti yang sama pada penerima. Penguraian kode (decoding) adalah penerima yang menerjemahkan pesan tersebut. Proses ini dapat menjadi sangat rumit. Arti dari beragam kata dan simbol mungkin berbeda, bergantung pada sikap dan pengalaman dari kedua kelompok. Orang-orang membutuhkan kerangka referensi yang sama untuk dapat berkomuniaksi secara efektif.

Menurut (Manap, 2016) dasarkan pengertian promosi di atas, dapat disimpulkan bahwa promosi itu adalah sejenis komunikasi yang memberi penjelasan yang menyatakan calon konsumen tentang barang dan jasa. Tujuan promosi ialah memperoleh perhatian, mendidik, mengingatkan, dan menyakinkan calon konsumen.

Menurut (Manap, 2016) Unsur Promosi, seperti diuangkapkan Philip Kotler dan Gary 
Armstrong (1991:432): The four major promotion tool are defined below:

1. Advertising, Any paid form of non-personel presentation and promotion of ideas good, or services by an identified sponsor.

2. Sales Promotion. Short-tern incentives to encourage purchase or sales of aproduct or services.

3. Public Relation. Building good relation with the company's various public by obtaining favorable publicity, buiding up good "corporate image" and handling or heading off unfavorable rumors, strories, and event. Artinya membangun hubungan baik dengan relasi perusahaan, agar nama baik perusahaan selalu terpelihara, dan melawan isu-isu negatif yang disebabkan oleh pihak lain.

4. Personal Selling. Oral presenttaion in a conversation with one or more prospective purchasers for the purchasers for the purhpse of making sales.

Menurut (Mashadi, 2018) Sebaliknya jika menggunakan transaksi non tunai, apa saja kelebihan? Ketika sebuah transaksi dilakukan dengan sitem non tunai, transaksi tidak saja hanya praktis sebab tidak adanya uang fisik yang harus dibawa. Namun juga bisa dilakukan di mana pun dan kapan pun. Bahkan antara pelaku transaksi pun tidak mesti harus bertemu dan bertatap muka langsung. Contoh praktis uang tunai yang ada seperti kartu ATM, kartu debit, dan kartu kredit. Ada layanan phone banking, internet banking, SMS banking dan mobile banking. Ada uang elektronik (e-money) yang berbentuk kartu atau aplikasi. Juga laynana transaksi via mesin EDC, poncel dengan cukup meamsukan kode indentifikasi pribadi saat bertransaksi lewat internet. Ke semua layanannya menjadikan lebih praktis, lebih aman, lebih nyaman. Lebih transparan, dan sangat hemat ruang.

Menurut (Sarwono, Jonathan dan K. Prihartono, 2012) Apa yang di maksud dengan transaksi keuangan secara online. Transaksi pembayaran online merupakan suatu sistem yang mendukung pengiriman uang atau dana dari pihak pembayar dan pihak yang menerima bayaran, umumnya melalaui pertukaran debit dan credit diantara institusi keungan yang dilakukan melalui mekanisme online.

Faktor-Faktor yang mempengaruhi perilaku konsumen online di antaranya ialah masalah harga, kepercayaan, dan kecocokan.
1. Harga dijadikan sebagai pembanding dalam mencari produk/ jasa yang dibutuhkan. Melalui membandingkan harga secara online, maka konsumen memperoleh kemudahan dalam memilih produk yang murah sesuai dengan harapan dan kemampuan membelinya (menurut Brassington \& Pettit dalam Jususf, Dewi Indriani (2018) Sementara itu, menurut Kotler dan Armstrong dalam (Jususf, 2018) selain harga juga ada produk, promosi, dan lokasi mengacu pada situs-situs pengecer atau penjual online yang sekaligus juga took online di mana konsumen memesan barang secara online dan pihak penjual akan mengirimkan barang tersebut sesaui denagn ketentuan mereka ke alamat konsumen.

2. Kepercayaan konsumen berkaitan dengan jaminan keamanan saat melakukan transaksi secara online, sehingga membuat konsumen mersa nyaman dalam melakukan transaksi (menurut Brassington \& Pettit dalam (Jususf, 2018).

3. Kenyamanan berbelanja secara online dipandang penting oleh konsumen karena konsumen merasa lebih mudah dan cepat dalam melakukan belanja secara online dibadingkan dengan melakukan transaksi pembelian secara tatap muka di bsinis konvensional. (Menurut Constantinides dalam (Jususf, 2018).

Tabel 1. Definisi Operasional Penelitian

\begin{tabular}{|c|c|c|c|}
\hline $\begin{array}{l}\text { Variabel } \\
\text { Penelitian }\end{array}$ & $\begin{array}{l}\text { Definisi } \\
\text { Operasional }\end{array}$ & Dimensi & Indikator \\
\hline $\begin{array}{l}\text { Strategi } \\
\text { Taktik } \\
\text { Value }\end{array}$ & $\begin{array}{l}\text { Semua } \\
\text { strategi dan } \\
\text { taktik yang } \\
\text { sudah } \\
\text { dirancang } \\
\text { akan berjalan } \\
\text { optimal jika } \\
\text { disertai } \\
\text { dengan } \\
\text { peningkatan } \\
\text { value dari } \\
\text { produk } \\
\text { dan/atau jasa. } \\
\text { Peningkatan } \\
\text { value berarti } \\
\text { mampu } \\
\text { membangun } \\
\text { merek yang } \\
\text { kuat, } \\
\text { memberikan } \\
\text { pelayanan }\end{array}$ & $\begin{array}{l}\text { Pelayanan } \\
\text { Konsumen }\end{array}$ & $\begin{array}{l}\text { Membuat } \\
\text { rasa } \\
\text { kepauasan } \\
\text { kepada } \\
\text { konsumen }\end{array}$ \\
\hline
\end{tabular}




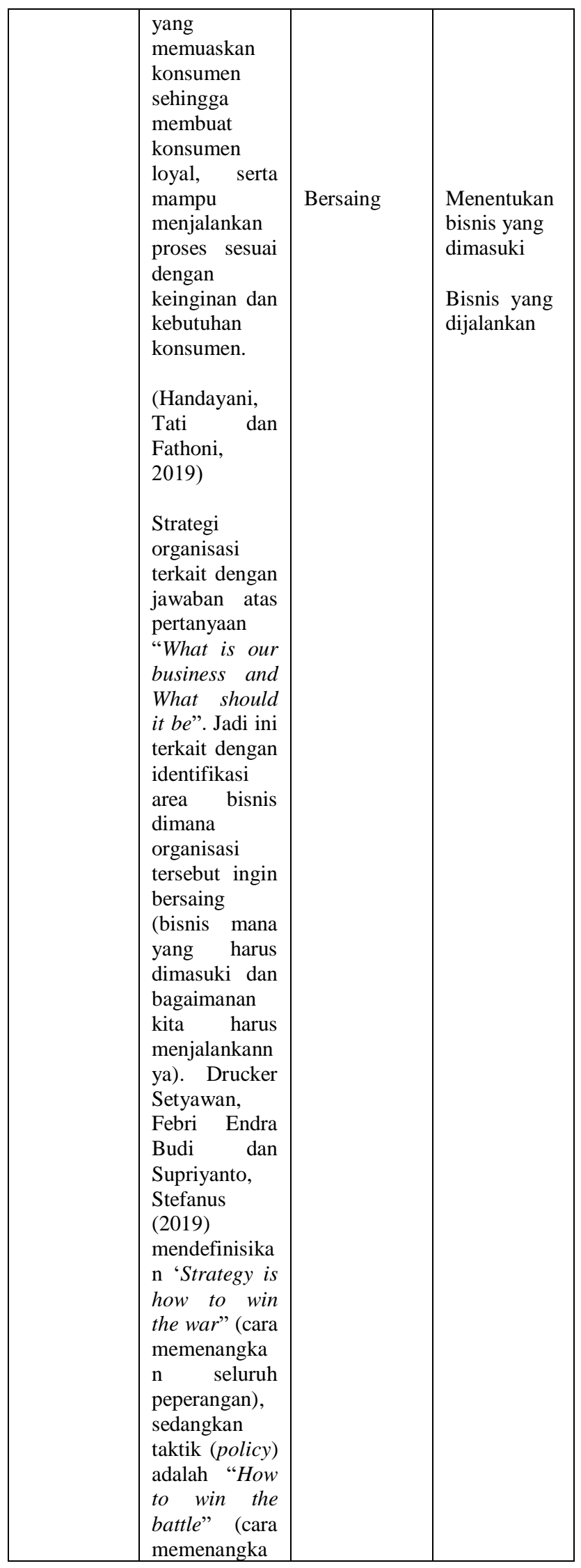

\begin{tabular}{|c|c|c|c|}
\hline & $\begin{array}{l}\mathrm{n} \\
\text { pertempuran). } \\
\text { (Setyawan, } \\
\text { Febri Endra } \\
\text { Budi dan } \\
\text { Supriyanto, } \\
2019 \text { ) }\end{array}$ & & \\
\hline $\begin{array}{l}\text { Kode } \\
\text { Promosi }\end{array}$ & $\begin{array}{l}\text { Promosi } \\
\text { adalah segala } \\
\text { bentuk } \\
\text { komunikasi } \\
\text { yang } \\
\text { digunakan } \\
\text { untuk } \\
\text { menginformas } \\
\text { ikan (to } \\
\text { inform), } \\
\text { membujuk (to } \\
\text { persuade) } \\
\text { atau } \\
\text { mengingatkan } \\
\text { orang-orang } \\
\text { tentang } \\
\text { produk yang } \\
\text { dihasilkan } \\
\text { organisasi, } \\
\text { individu } \\
\text { ataupun } \\
\text { rumah tangga } \\
\text { (Evans dan } \\
\text { Berman } \\
\text { dalam } \\
\text { Simamora, } \\
\text { Bilson. 2003) } \\
\text { (Simamora, } \\
\text { 2003) }\end{array}$ & $\begin{array}{l}\text { Informasi } \\
\text { Membujuk }\end{array}$ & $\begin{array}{l}\text { Memberikan } \\
\text { informasi } \\
\text { pewaran } \\
\text { Mempengar } \\
\text { uhi } \\
\text { konsumen } \\
\text { agar } \\
\text { membeli } \\
\text { barang } \\
\text { melalui kode } \\
\text { promosi } \\
\text { Dengan } \\
\text { promo orang } \\
\text { akan } \\
\text { menjadi } \\
\text { ingat }\end{array}$ \\
\hline $\begin{array}{l}\text { Motivasi } \\
\text { Pembelian }\end{array}$ & $\begin{array}{l}\text { Motivasi yang } \\
\text { dipengaruhi } \\
\text { emosi } \\
\text { berkaitan } \\
\text { dengan } \\
\text { perasaan, baik } \\
\text { itu keindahan, } \\
\text { gensi, atau } \\
\text { perasaan } \\
\text { lainnya } \\
\text { termasuk } \\
\text { bahkan iba } \\
\text { dan rasa } \\
\text { marah. } \\
\text { Sikap belanja } \\
\text { rasional } \\
\text { dipengaruhi } \\
\text { oleh alasan } \\
\text { rasional } \\
\text { dalam pikiran } \\
\text { seseorang } \\
\text { konsumen. } \\
\text { (Ma'ruf, }\end{array}$ & Rasional & $\begin{array}{l}\text { Gensi } \\
\text { Rasa } \\
\text { Kasihan } \\
\text { Rasa Marah }\end{array}$ \\
\hline
\end{tabular}




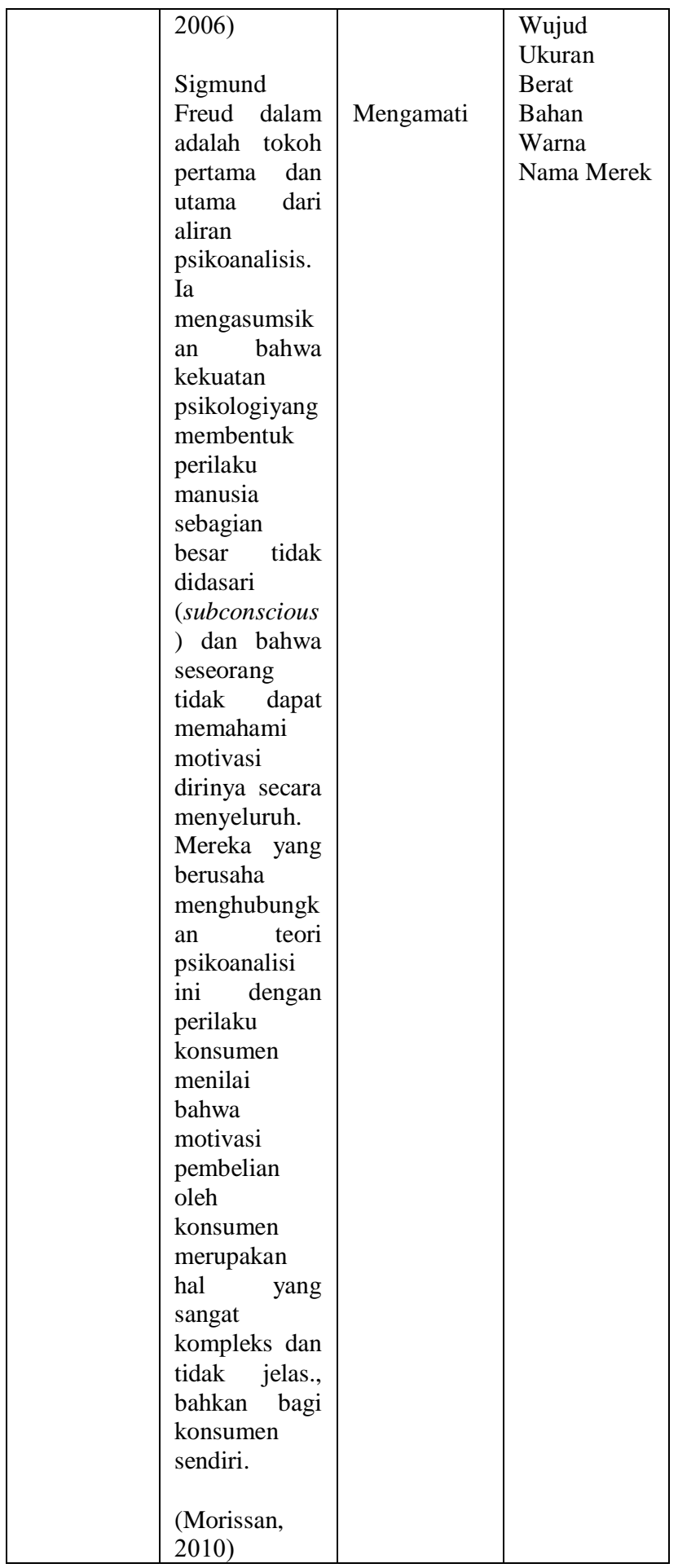

\section{METODE PENELITIAN}

\section{Populasi dan Sampel}

Populasi menurut Sugiyono dalam "adalah wilayah generalisasi yang terdiri atas obyek atau subyek yang mempunyai kualitas dan karakteristik tertentu yang ditetapkan oleh peneliti untuk dipelajari dan kemudian ditarik kesimpulnnya".

(Rukajat, 2018b) Data primer yaitu data yang langsung diperoleh langsung dari obyek yang diteliti dan kemudian diolah oleh penulis.

Menurut swa.co.id jumlah pengguna grab sebanyak 138.000.000 juta, jumlah ini merupakan populasi. Berdasarkan populasi tersebut maka diambil sampel dengan menggunakan rumus slovin.

$$
\mathrm{n}=\frac{N}{1+N e^{2}}
$$

Ket:

$\mathrm{n}=$ jumlah sampel

$\mathrm{N}=$ jumlah populasi

e: batas toleransi kesalahan (error tolerance)

$$
\begin{aligned}
n & =\frac{138.000 .000}{1+138.000 .000 \times .0 .05^{2}} \\
& =\frac{138.000 .000}{138.000 .001 \times 0.0025} \\
& =\frac{138.000 .000}{345.000,0025} \\
& =3999,999(400)
\end{aligned}
$$

\section{Kerangka berpikir}

Menurut (Unaradjan, 2019) Kerangka berpikir atau kerangka pemikiran adalah dasar pemikiran dari penelitian yang diisntesiskan dari fakta-fakta, observasi dan telaah kepustakaan. Oleh karena itu, kerangka berpikir memuat teori, dalil atau konsepkonsep yang akan dijadikan dasar dalam penelitian.

Uraian dalam kerangka berpikir menjelaskan hubungan dan keterkiatan antar variabel penelitian. 


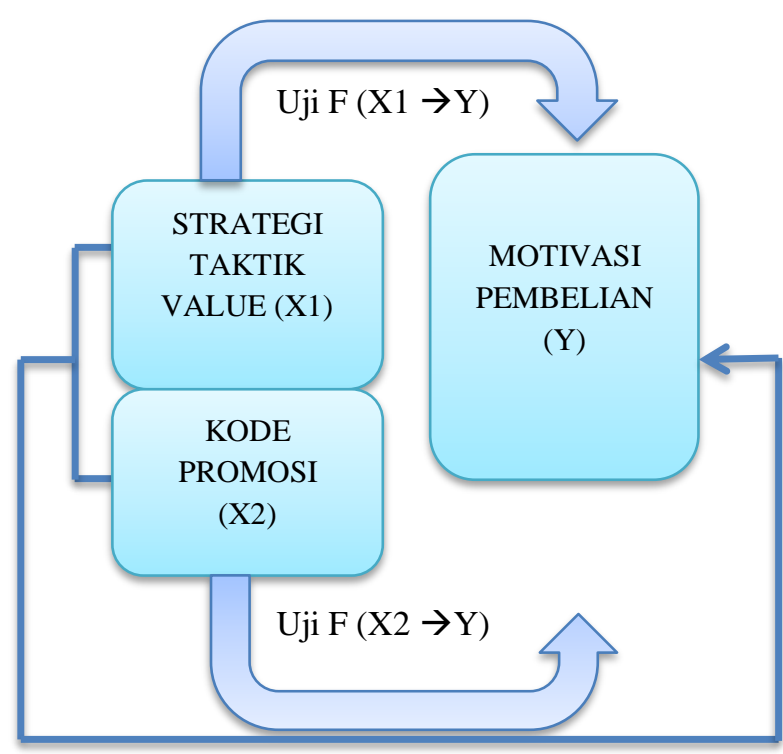

Uji $\mathrm{t}(\mathrm{X} 1$ dan $\mathrm{X} 2 \rightarrow \mathrm{Y})$

Gambar 3. Kerangka Pemikiran

\section{Hipotesis}

Menurut (Unaradjan, 2019) Dengan kerangka berpikir ini selanjutnya dapat digunakan untuk menyususn hipotesis. Hipotesis meruapakan jawaba sementara terhadap rumusan masalah atau sub amasalah yang diajukan oleh peneliti, yang dijabrakan dari landasan teori atau kajian teori dan masih harus diuji kebenarannya.

Hipotesis untuk uji $\mathrm{t}$

$\mathbf{H}_{0}$ : Tidak terdapat pengaruh antara Strategi Taktik Value terhadap Motivasi Pembelian

$\mathbf{H}_{\mathbf{a}}$ : Terdapat pengaruh antara Strategi Taktik Value terhadap Motivasi Pembelian

$\mathbf{H}_{\mathbf{0}}$ : Tidak terdapat pengaruh antara Kode Promosi terhadap Motivasi Pembelian

$\mathbf{H}_{\mathrm{a}}$ : Terdapat pengaruh antara Kode Promosi terhadap Motivasi Pembelian

Hipotesis untuk uji $\mathrm{F}$

$\mathbf{H}_{0}$ : Tidak Terdapat pengaruh antara Strategi Taktik Value Dan Kode Promosi Terhadap Motivasi Pembelian Makanan Secara Online Melalui Grab

$\mathbf{H}_{\mathbf{a}}$ : Terdapat pengaruh antara Strategi Taktik Value Dan Kode Promosi Terhadap Motivasi Pembelian Makanan Secara Online Melalui Grab

\section{HASIL DAN PEMBAHASAN}

Menurut (Suryani dan Hendryadi, 2015) Validitas mengacu pada aspek ketepatan dan kecermatan hasil pengukuran. Pengukuran sendiri dilakukan untuk mengetahui seberapa banyak aspek (dalam arti kuantitatif) suatu aspek psikologis terdapat dalam diri seseorang, yang dinyatakan oleh skornya pada instrumen pengukur yang bersangkutan.

(Rukajat, 2018b) Pengujian validitas instrumen digunakan untuk mengukur sampai seberapa besar ketepatan dan kecermatan suatu alat ukur didalam melakukan fungsinya. Menurut Sugiyono dalam (Rukajat, 2018b) Pengujian instrumen dapat dilakukan analisis faktor, yaitu mengkorelasikan antara skor item instrument dalam suatu faktor, dan mengkorelasikan skor faktor dengan skor total. Bila korelasi tiap faktor positif dan besarnya $>0,3$, maka dapat disimpulkan instrumen tersebut valid.

Tabel 2. Uji Validitas

\begin{tabular}{|c|c|c|c|}
\hline $\begin{array}{c}\text { No Butir } \\
\text { Item (X1) }\end{array}$ & rhasil & rtabel & Kesimpulan \\
\hline 1 & 0,834 & 0,098 & Valid \\
\hline 2 & 0,876 & 0,098 & Valid \\
\hline 3 & 0,895 & 0,098 & Valid \\
\hline 4 & 0,602 & 0,098 & Valid \\
\hline 5 & 0,891 & 0,098 & Valid \\
\hline 6 & 0,943 & 0,098 & Valid \\
\hline 7 & 0,738 & 0,098 & Valid \\
\hline 8 & 0,862 & 0,098 & Valid \\
\hline 9 & 0,873 & 0,098 & Valid \\
\hline 10 & 0,926 & 0,098 & Valid \\
\hline 11 & 0,846 & 0,098 & Valid \\
\hline 12 & 0,684 & 0,098 & Valid \\
\hline 13 & 0,864 & 0,098 & Valid \\
\hline
\end{tabular}

Sumber : Hasil Olah Data SPSS 2019

Tabel 3. Uji Validitas X2

\begin{tabular}{|c|c|c|c|}
\hline $\begin{array}{c}\text { No Butir } \\
\text { Item } \\
\text { (X2) }\end{array}$ & rhasil & r tabel & Kesimpulan \\
\hline 1 & 0,888 & 0,098 & Valid \\
\hline 2 & 0,848 & 0,098 & Valid \\
\hline 3 & 0,844 & 0,098 & Valid \\
\hline 4 & 0,637 & 0,098 & Valid \\
\hline 5 & 0,844 & 0,098 & Valid \\
\hline 6 & 0,945 & 0,098 & Valid \\
\hline 7 & 0,707 & 0,098 & Valid \\
\hline 8 & 0,879 & 0,098 & Valid \\
\hline 9 & 0,880 & 0,098 & Valid \\
\hline 10 & 0,910 & 0,098 & Valid \\
\hline 11 & 0,839 & 0,098 & Valid \\
\hline 12 & 0,739 & 0,098 & Valid \\
\hline 13 & 0,798 & 0,098 & Valid \\
\hline
\end{tabular}


Tabel 4. Uji Validitas Y

\begin{tabular}{|c|c|c|c|}
\hline $\begin{array}{c}\text { No Butir } \\
\text { Item (Y) }\end{array}$ & rhasil & $\mathbf{r}_{\text {tabel }}$ & Kesimpulan \\
\hline 1 & 0,804 & 0,098 & Valid \\
\hline 2 & 0,914 & 0,098 & Valid \\
\hline 3 & 0,892 & 0,098 & Valid \\
\hline 4 & 0,519 & 0,098 & Valid \\
\hline 5 & 0,892 & 0,098 & Valid \\
\hline 6 & 0,906 & 0,098 & Valid \\
\hline 7 & 0,644 & 0,098 & Valid \\
\hline 8 & 0,807 & 0,098 & Valid \\
\hline 9 & 0,909 & 0,098 & Valid \\
\hline 10 & 0,860 & 0,098 & Valid \\
\hline 11 & 0,755 & 0,098 & Valid \\
\hline 12 & 0,891 & 0,098 & Valid \\
\hline 13 & 0,898 & 0,098 & Valid \\
\hline
\end{tabular}

Sumber : Hasil Olah Data SPSS 2019

Menurut Sugiyono dalam (Rukajat, 2018a) Dasar pengambilan keputusan dalam uji validitas adalah sebagai berikut:

Apabila nilai $r_{\text {hasil }}$ positif serta $r_{\text {hasil }}>r_{\text {tabel }}$, maka butir atau variabel tersebut valid.

Apabila nilai $r_{\text {hasil }}$ negatif dan $r_{\text {hasil }}<\mathrm{rt}_{\text {abel }}$ atau pun $\mathrm{r}_{\text {hasil }}$ negatif $>r_{\text {tabel }}$ maka butir atau variabel tersebut tidak valid.

Berdasarkan hasil uji validitas dari ketiga variabel yakni varibael $\mathrm{X} 1, \mathrm{X} 2$ dan $\mathrm{Y}$ menunjukkan rhasil>rtabel maka dapat disimpulkan bahwa ketiga variabel tersebut valid.

\section{Uji Realibilitas}

Menurut Sugiyono dalam (Rukajat, 2018a) "Instrumen yang realibel/handal adalah instrumen yang bila digunakan beberapa kali untuk mengukur objek yang sama, akan menghasilkan data yang sama".

Tabel 5. Uji Realibilitas Strategi Taktik Value (X1) Case Processing Summary

\begin{tabular}{|l|l|r|r|}
\hline \multicolumn{2}{|c|}{} & $\mathrm{N}$ & \multicolumn{1}{c|}{$\%$} \\
\hline \multirow{3}{*}{ Cases } & Valid $^{2}$ & 400 & 100.0 \\
\cline { 2 - 4 } & Excluded & & \\
\cline { 2 - 4 } & Total & 0 & .0 \\
\hline \multirow{2}{*}{ a } & & 400 & 100.0 \\
\hline
\end{tabular}

a. Listwise deletion based on all variables in the procedure.

\begin{tabular}{|r|r|}
\hline \multicolumn{2}{|c|}{ Reliability Statistics } \\
\hline Cronbach's Alpha & N of Items \\
\hline .955 & 13 \\
\hline
\end{tabular}

Sumber : Hasil Olah Data SPSS 2019

Tabel 6. Uji Realibilitas Strategi Taktik Value Kode Promosi (X2)

Case Processing Summary

\begin{tabular}{|l|l|r|r|}
\hline \multicolumn{2}{|c|}{} & \multicolumn{1}{|c|}{$\mathrm{N}$} & \multicolumn{1}{c|}{$\%$} \\
\hline \multirow{3}{*}{ Cases } & Valid $^{2}$ & 400 & 100.0 \\
\cline { 2 - 4 } & Excluded $^{\mathrm{a}}$ & 0 & .0 \\
\cline { 2 - 4 } & Total & 400 & 100.0 \\
\hline
\end{tabular}

a. Listwise deletion based on all variables in the procedure.

Reliability Statistics

\begin{tabular}{|r|r|}
\hline Cronbach's Alpha & N of Items \\
\hline .952 & 13 \\
\hline
\end{tabular}

Sumber : Hasil Olah Data SPSS 2019

Tabel 7. Uji Realibilitas Motivasi Pembelian (Y) Case Processing Summary

\begin{tabular}{|l|l|r|r|}
\hline \multicolumn{2}{|c|}{} & $\mathrm{N}$ & \multicolumn{1}{c|}{$\%$} \\
\hline \multirow{3}{*}{ Cases } & Valid $^{*}$ & 400 & 100.0 \\
\cline { 2 - 4 } & Excluded $^{\mathrm{a}}$ & 0 & .0 \\
\cline { 2 - 4 } & Total & 400 & 100.0 \\
\hline
\end{tabular}

a. Listwise deletion based on all variables in the procedure.

\section{Reliability Statistics}

\begin{tabular}{|l|l|}
\hline Cronbach's Alpha & N of Items \\
\hline
\end{tabular}

\begin{tabular}{ll}
.953 & 13 \\
\hline
\end{tabular}

Sumber : Hasil Olah Data SPSS 2019

Menurut (Rukajat, 2018a) Uji Realibilitas menujukkan kemampuan instrumen penelitian untuk mengungkap data yang dapat dipercaya. Menurut Arikunto dalam (Rukajat, 2018a) dalam penelitian ini akan digunakan analisis realibilitas internal dengan menggunakan Alpha Chronbach.

Dasar pengambilan keputusan dalam uji realibilitas pada penelitian ini adalah sebagai berikut:

Apabila nilai $r$ Alpha positif dan $r$ Alpha $>r_{\text {tabel }}$ maka butir atau variabel tersebut Reliabel.

\section{Uji F}

Tabel 8. Uji F

ANOVA

\begin{tabular}{|l|r|r|r|c|c|}
\hline Model & $\begin{array}{r}\text { Sum of } \\
\text { Squares }\end{array}$ & df & $\begin{array}{c}\text { Mean } \\
\text { Square }\end{array}$ & F & Sig. \\
\hline Regression & $\begin{array}{r}17787.3 \\
95\end{array}$ & 2 & 8893.697 & 4253.381 & $.000^{\mathrm{b}}$ \\
\hline Residual & 830.115 & 397 & 2.091 & & \\
\hline Total & $\begin{array}{r}18617.5 \\
10\end{array}$ & 399 & & & \\
\hline
\end{tabular}

a. Dependent Variable: Motivasi Pembelian (Y)

b. Predictors: (Constant), Kode Promosi (X2), Strategi

Taktik Value (X1) 
Dalam penelitian yang dilakukan (Haslinda dan Jamaluddin M, 2016) menjelaskan bahwa untuk Melihat $\mathrm{F}$ hitung dengan melihat output (tabel anova) SPSS 22 dan membandingkannya dengan $\mathrm{F}$ tabel. Menentukan kriteria penerimaan dan penolakan Ho, dengan melihat tingkat probabilitasnya, yaitu :

Jika Signifikansi < 0,05 maka Ho ditolak

Jika Signifikansi > 0,05 maka Ho diterima

Hasil uji F hitung menujukkan bahwa nilai Sig. 0,000 < 0,05 maka H0 ditolak maka dapat disimpulkan Terdapat pengaruh signifikan antara Strategi Taktik Value (X1) dan Kode Promosi (X2) Terhadap Motivasi Pembelian (Y).

Menurut (Rukajat, 2018b) Uji F digunakan untuk mengetahui signifikan atau tidaknya variabel independen (X1 dan X2) secara simultan terhadap variabel dependen (Y) yakni : Strategi Taktik Value (X1) dan variabel Kode Promosi (X2) terhadap variabel Motivasi Pembelian (Y).

Setelah dialkukan Uji Fhitung keputusan uji f-nya sebagai berikut ini:

$\mathrm{H}_{0}=$ Tidak ada pengaruh Strategi Taktik Value dan Kode Promosi Terhadap Motivasi Pembelian, jika $F_{\text {hitung }}<$ dari $F_{\text {tabel }}$

$\mathrm{H}_{\mathrm{a}}=$ Terdapat pengaruh signifikan antara Strategi Taktik Value dan Kode Promosi Terhadap Motivasi Pembelian, jika $F_{\text {hitung }}>$ dari $F_{\text {tabel }}$

Penentuan nilai kritis dari Fhitung dilanjutkan dikonsultasikan dengan $F_{\text {tabel }}$. Untuk derajat kebebasan (DK) pembilang 2 dan derajat kebebasan penyebut (n-k-1) tingkat signifikansinya $(\alpha) \quad 5 \%$ maupun $1 \%$.

Hasil perhitungan menujukkan bahwa $\mathrm{F}_{\text {hitung }} 4253.381$ $>\mathrm{F}_{\text {tabel }}$ 3,01 maka $\mathrm{H}_{0}$ ditolak dan $\mathrm{H}_{\mathrm{a}}$ diterima, dapat disimpulkan terdapat pengaruh signifikan antara Terdapat pengaruh signifikan antara Strategi Taktik Value (X1) dan Kode Promosi (X2) Terhadap Motivasi Pembelian (Y).

\section{Uji T}

Menurut (Payadnya, I Putu Ade Andre dan Jayantika, 2018) Uji hipotesis Strategi Taktik Value (X1)

$\mathrm{H}_{0} \quad$ :Pernyataan atau dugaan yang menyatakan tidak terdapat pengaruh antara Strategi Taktik Value terhadap Motivasi Pembelian

$\mathrm{H}_{\mathrm{a}} \quad$ :Pernyataan atau dugaan yang menyatakan terdapat pengaruh antara Strategi Taktik Value terhadap Motivasi Pembelian
Menentukan resiko kesalahan $\alpha$ (taraf signifikansi / probabilitas) dan Kriteria Pengujian.

Jika $\mathrm{t}$ tabel $\leq \mathrm{t}$ hitung, maka $\mathrm{H}_{0}$ ditolak

Jika $\mathrm{t}$ tabel $>\mathrm{t}$ hitung, maka $\mathrm{H}_{0}$ diterima

1,966 $\leq 7,777$ maka $\mathrm{H}_{0}$ ditolak, dengan demikian terdapat pengaruh antara Strategi Taktik Value terhadap Motivasi Pembelian

Uji hipotesis Kode Promosi (X2)

$\mathrm{H}_{0}$ : Tidak terdapat pengaruh antara Kode Promosi terhadap Motivasi Pembelian

$\mathrm{H}_{\mathrm{a}}$ : Terdapat pengaruh antara Kode Promosi terhadap Motivasi Pembelian

1,966 $\leq 21,572$ maka $\mathrm{H}_{0}$ ditolak, dengan demikian Terdapat pengaruh antara Kode Promosi terhadap Motivasi Pembelian

Tabel 9. Uji t

Sumber : Hasil Olah Data SPSS 2019

\section{Uji Regresi}

Menurut (Nachrowi, Djalal Nachrowi dan Usman, 2004) Selanjutnya akan didapat tabel yang berinisial "Model Summary". Tabel ini akan memberikan informasi tentang keeratan hubungan antara kedua variabel. Ada pun ukuran yang biasa digunakan adalah $\mathrm{R}$ square atau biasa ditulis R2. Angka ini menujukkan seberapa besar variasi varibel bebas dapat menerangkan variabel terikat. Untuk kasus ini didapat angka 0,955 , yang berarti motivasi pembelian dapat diterangkan oleh Kode Promosi (X2) dan Strategi Taktik Value (X1) sebesar 95,5\% sedangkan sisanya diterangkan oleh variabel lain-lain.

Tabel 10. Uji Regresi

Coefficients $^{\mathrm{a}}$

\begin{tabular}{|c|c|c|c|c|c|}
\hline \multirow[t]{2}{*}{ Model } & \multicolumn{2}{|c|}{$\begin{array}{l}\text { Unstandardized } \\
\text { Coefficients }\end{array}$} & \multirow{2}{*}{$\begin{array}{c}\text { Standardized } \\
\text { Coefficients } \\
\text { Beta }\end{array}$} & \multirow[t]{2}{*}{$\mathrm{t}$} & \multirow[t]{2}{*}{ Sig. } \\
\hline & B & $\begin{array}{l}\text { Std. } \\
\text { Error }\end{array}$ & & & \\
\hline (Constant) & -1.731 & .603 & & -2.872 & .004 \\
\hline $\begin{array}{l}\text { Strategi } \\
\text { Taktik } \\
\text { Value (X1) }\end{array}$ & .273 & .035 & .262 & 7.777 & .000 \\
\hline $\begin{array}{l}\text { Kode } \\
\text { Promosi } \\
(\mathrm{X} 2) \\
\end{array}$ & .731 & .034 & .726 & 21.572 & .000 \\
\hline
\end{tabular}

a. Dependent Variable: Motivasi Pembelian (Y) 


\section{KESIMPULAN}

Berdasarkan hasil penelitian yang dilakukan maka dapat diambil suatu kesimpulan antara ketiga varibel yakni variabel Strategi Taktik Value (X1), Kode

Model Summary ${ }^{\mathrm{b}}$

\begin{tabular}{|l|l|l|l|l|l|}
\hline $\begin{array}{l}\text { Mode } \\
1\end{array}$ & $\mathrm{R}$ & $\begin{array}{l}\mathrm{R} \\
\text { Square }\end{array}$ & $\begin{array}{l}\text { Adjusted R } \\
\text { Square }\end{array}$ & $\begin{array}{l}\text { Std. } \\
\text { Error of } \\
\text { the } \\
\text { Estimate }\end{array}$ & $\begin{array}{l}\text { Durbin- } \\
\text { Watson }\end{array}$ \\
\hline 1 & $.977^{\mathrm{a}}$ & .955 & .955 & 1.446 & 2.213 \\
\hline
\end{tabular}
a. Predictors: (Constant), Kode Promosi (X2), Strategi Taktik
Value (X1)
b. Dependent Variable: Motivasi Pembelian (Y)
Sumber : Hasil Olah Data SPSS 2019

Promosi (X2) dan Motivasi Pembelian (Y). Hasil pengujian dengan uji $\mathrm{t}$ menujukkan bahwa nilai $\mathrm{t}$ tabel $\leq \mathrm{t}$ hitung maka dapat disimpulkan terdapat pengaruh Strategi Taktik Value terhadap Motivasi Pembelian. Sementara itu untuk Strategi Taktik Value memiliki pengaruh terhadap Motivasi Pembeliaan yang ditunjukkan dengan nilai $\mathrm{t}$ tabel $\leq \mathrm{t}$ hitung. Sementara itu hasil regresi menujukkan nilai Adjusted R Square 0,955 yang merangkan bahwa besarnya kontribusi atau sumbangan pengaruh varaiabel Strategi Taktik Value (X1) dan Kode Promosi (X2) Terhadap Motivasi Pembelian sebesar $95,5 \%$ sementara itu sisanya $4,5 \%$ dipengaruhi faktor lain yang tidak diteliti dalam penelitian ini.

\section{REFERENSI}

Cannon, J. P. (2009). Pemasaran Dasar. Jakarta: Salemba Empat.

Handayani, Tati dan Fathoni, M. A. (2019). Buku Ajar Manajemen Pemasaran Islam. Yogyakarta: Deepublish.

Haslinda dan Jamaluddin M. (2016). Pengaruh Perencanaan Anggaran Dan Evaluasi Anggaran Terhadap Kinerja Organisasi Dengan Standar Biaya Sebagai Variabel Moderating Pada Pemerintah Daerah Kabupaten Wajo. Jurnal Ilmiah Akuntansi Peradaban, Vol. II No.

Jususf, D. I. (2018). Perilaku Konsumen di Masa Bisnis Online. Yogyakarta: ANDI.

Kurtajaya, H. (2002). Mark Plus on Strategy. Jakarta: PT Gramedia Pustaka Utama.

Ma'ruf, H. (2006). Pemasaran Ritel. Jakarta: Gramedia Pustaka Utama.
Manap, H. A. (2016). Revolusi Manajemen Pemasaran. Jakarta: Mitra Wacana Media.

Mashadi, M. (2018). Akuntabilitas Ideal. Yogyakarta: Deepublish.

Morissan. (2010). Periklanan Komunikasi Pemasaran Terpadu. Jakarta: Prenadamedia Group.

Nachrowi, Djalal Nachrowi dan Usman, H. (2004). Teknik Pengambilan Keputusan. Jakarta: Grasindo.

Payadnya, I Putu Ade Andre dan Jayantika, I. G. A. N. T. (2018). Panduan Penelitian Eksperimen Beserta Analisis Statistik Dengan SPSS. Yogyakarta: Deepublish.

Rinaldo dan Hardi. (2016). 9 Jurus Jitu Pemasaran UKM WOW. Jakarta: PT Gramedia Pustaka Utama.

Rukajat, A. (2018a). Pendekatan Penelitian Kuantitatif. Jakarta: Deepublish.

Rukajat, A. (2018b). Pendekatan Penelitian Kuantitatif Quantitative Research Approach. Yogyakarta: Deepublish.

Sarwono, Jonathan dan K. Prihartono, A. . (2012). Perdagangan Online: Cara Bisnis di Internet. Jakarta: PT. Elex Media Komputindo.

Setyawan, Febri Endra Budi dan Supriyanto, S. (2019). Manajemen Rumah Sakit. Sidoarjo: Zifatama Jawara.

Simamora, B. (2003). Memenangkan Pasar Dengan Pemasaran Efektif dan Profitabel. Jakarta: PT. Gramedia Pustaka Utama.

Suryani dan Hendryadi. (2015). Metode Riset Kuantitatif Teori dan Aplikasi Pada Penelitian Biding Manajemen dan Ekonomi Islam. Jakarta: Prenadamedia Group.

Unaradjan, D. D. (2019). Unaradjan, Dominikus Dolet. Jakarta: Universitas Katolok Indonesia Atma Jaya. 